\title{
Oligosaccharides from human milk induce growth arrest via G2/M by influencing growth-related cell cycle genes in intestinal epithelial cells
}

\author{
Sabine Kuntz ${ }^{1}$, Clemens Kunz ${ }^{1}$ and Silvia Rudloff ${ }^{2}$ \\ ${ }^{1}$ Institute of Nutritional Science, University of Giessen, Wilhelmstrasse 20, 35392 Giessen, Germany \\ ${ }^{2}$ Department of Pediatrics, University of Giessen, Feulgenstrasse 9, 35392 Giessen, Germany
}

(Received 18 March 2008 - Revised 6 June 2008 - Accepted 9 July 2008 - First published online 15 December 2008)

Oligosaccharides are present in human milk in large amounts and in a high variety. We have previously shown that these oligosaccharides are strong inhibitors of proliferation and inducers of differentiation in intestinal cell lines. To elucidate the molecular mechanism, we investigated the influence on cell cycle events via flow cytometry and expression levels by using quantitative real-time RT-PCR. Human intestinal cells, i.e. HT-29, HIEC and Caco-2 cells, were exposed to neutral or acidic human milk oligosaccharides. Both fractions induced a concentration-dependent G2/M arrest. Cell cycle analysis for HT-29 revealed $37 \%$ of cells in G1 and 35\% in G2/M (neutral oligosaccharides) and incubation with acidic oligosaccharides led to $42 \%$ cells in G1 and $40 \%$ in G2/M. In control experiments without oligosaccharides we found $71 \%$ of cells to be in G1 and $17 \%$ in G2/M. This G2/M arrest was associated with changes in mRNA expression of cyclin A and B. A G2/M arrest with concomitant alterations of cell cycle gene expression could also be shown for HIEC and Caco-2 cells. Analysing the expression of cyclin-dependent kinase inhibitors $\mathrm{p} 21^{c i p l}$ and $\mathrm{p} 27^{k i p 1}$ and the tumour suppressor $\mathrm{p} 53$ we observed that the expression of $\mathrm{p} 21^{\text {cip } 1}$ was p53-independent and necessary for arresting cells in the G2/M phase, while p $27^{\text {kip } 1}$ was associated with differentiation effects. Both neutral and acidic human milk oligosaccharides were able to induce epidermal growth factor receptor, extracellular signal-regulated kinase $1 / 2$ and p38 phosphorylation. These results suggest that oligosaccharides from human milk inhibited intestinal cell proliferation and altered cell cycle dynamics by affecting corresponding regulator genes and mitogen-activated protein kinase signalling.

Oligosaccharides: G2/M arrest: Cyclins: Cyclin-dependent kinase inhibitors: Mitogen-activated protein kinase signalling

Human milk oligosaccharides (HMO) are currently discussed as participating in the development of a normal microflora in neonates, as soluble receptors for pathogens preventing their adhesion to the epithelial cells and as modulators of inflammatory processes ${ }^{(1-4)}$. The total oligosaccharide content in human milk ranges from 5 to $15 \mathrm{~g} / \mathrm{l}$ compared to about $1 \mathrm{~g} / \mathrm{l}$ in mature bovine milk ${ }^{(5-8)}$. Neutral oligosaccharides comprise about $70 \%$ of the total oligosaccharide content in human milk, whereas acidic oligosaccharides account for $30 \%{ }^{(9)}$. As the intestine of the breast-fed infant is continuously exposed to such high concentrations of oligosaccharides for up to several months, it is intriguing to consider whether ingested oligosaccharides may modulate neonatal intestinal development. Recent studies using the intestinal cell line Caco-2 revealed that specific neutral oligosaccharides are minimally digested, could in part be taken up and get enriched by intestinal cells ${ }^{(10-12)}$. Hence, they might have the potential to affect enterocyte function.

Renewal of the intestinal villi is a well-regulated sequential process of proliferation, differentiation and apoptosis. We have recently shown that neutral and acidic HMO were able to reduce cell proliferation and enhance alkaline phosphatase activity particularly in undifferentiated cell lines ${ }^{(13)}$. However, up to now, no information is available regarding a direct effect of HMO on intestinal cell integrity and the mechanisms involved. Processes affecting cell fate are highly regulated and cell cycle genes like cyclins, cyclin-dependent kinases (CDK) and inhibitors play an important role in that context ${ }^{(14,15)}$. Dependent on their level of expression, cyclins regulate cell progression and are responsible for arresting cells at a defined state. Various molecular studies showed that a G1 arrest is associated with a decrease in cyclin D and cyclin $\mathrm{E}^{(16,17)}$. This decrease was found to be associated with changes in CDK protein levels and activity. Concomitant to these changes CDK inhibitors such as p2 $7^{\text {kipl }}$ and p21 $1^{\text {cipl }}$ were up-regulated and arrested cells in cell cycle phase $\mathrm{G} 1$ or $\mathrm{G} 2^{(18,19)}$.

Although most of the in vitro studies on $\mathrm{p} 21^{\text {cip } 1}$ regulation have concentrated on p53-dependent and p53-independent transcriptional regulation, a series of new studies has shown that $\mathrm{p} 21^{\text {cipl }}$ can be regulated by post-translational mechanisms. Phosphorylation of $\mathrm{p} 21^{\text {cip } 1}$ modulates not only interaction and binding with target proteins but also its stabilization $^{(20)}$. These phosphorylation events in cell cycle

Abbreviations: CDK, cyclin-dependent kinase; CDKI, cyclin-dependent kinase inhibitors; Ct, cycle threshold; EGFR, epidermal growth factor receptor; ERK, extracellular signal-regulated kinase; HMO, human milk oligosaccharides; MAPK, mitogen-activated protein kinase.

* Corresponding author: Dr Sabine Kuntz, fax +49 6419939049, email Sabine.Kuntz@ernaehrung.uni-giessen.de 
progression occur through different signal cascades such as receptor-mediated MAPK activation which could result in both $\mathrm{G} 1$ and $\mathrm{G} 2$ arrest.

Thus, the objective of the present study was to investigate how oligosaccharides induce inhibition of cell proliferation and which mechanism participates in these intestinal cell dynamics.

\section{Materials and methods \\ Isolation of human oligosaccharides from human milk and human milk oligosaccharide preparation}

Oligosaccharides were isolated from human milk as described previously $^{(7,13,21)}$. Briefly, after centrifugation, the lipid layer was removed, and the proteins were precipitated from the aqueous phase with ice-cold ethanol. Lactose was removed by gel filtration on Sephadex G-25 (Pharmacia Biotech, Uppsala, Sweden). The total oligosaccharide fraction was further separated into an acidic fraction (acidic HMO), consisting of compounds with $\mathrm{N}$-acetylneuraminic acid residues, and a neutral fraction (neutral HMO) without $N$-acetylneuraminic acid residues, using HPLC anion-exchange on a Resource Q column (Pharmacia Biotech) at the following conditions: $100 \%$ eluent $\mathrm{A}\left(\mathrm{H}_{2} \mathrm{O}\right)$ from 0 to $7.5 \mathrm{~min}$, a linear gradient to $55 \%$ eluent $\mathrm{B}(0.6 \mathrm{M}-\mathrm{NaCl})$ for $42.5 \mathrm{~min}$, a linear gradient to $100 \%$ eluent $\mathrm{B}$ for $2 \mathrm{~min}$, and a constant flow with $100 \%$ eluent $B$ for $8 \mathrm{~min}$. A flow rate of $2 \mathrm{ml} / \mathrm{min}$ was used. The eluting fractions were monitored at $214 \mathrm{~nm}$. Afterwards, pooled HPLC fractions were desalted by gel filtration on Sephadex G-25 (Pharmacia Biotech).

\section{Cell culture}

The human colon cancer cell line HT-29 was obtained from the American Type Culture Collection (Rockville, MD, USA); Caco-2 cells were a gift from R. K. Kinne (Max Planck Institute of Molecular Physiology, Dortmund, Germany). The fetal intestinal colon cell line HIEC was generously donated by J. F. Beaulieu (Department of Anatomy and Cell Biology, Faculty of Medicine, Université de Sherbrooke, Sherbrooke, Quebec, Canada) ${ }^{(22)}$. Cells were cultured in $75 \mathrm{~cm}^{2}$ tissue culture flasks (Renner, Darmstadt, Germany) in RPMI 1640 (HT-29 and HIEC) or Dulbecco's modified Eagle's medium (Caco-2) supplemented with $10 \%$ fetal calf serum, 2 mM-glutamine (Invitrogen, Karlsruhe, Germany), 100 units $/ \mathrm{ml}$ penicillin and $100 \mathrm{mg} / \mathrm{ml}$ streptomycin (Invitrogen). The cultures were kept in a humidified atmosphere of $5 \% \mathrm{CO}_{2}$ at $37^{\circ} \mathrm{C}$. Cells were passaged at preconfluent densities using $0.05 \%$ trypsin and $0.5 \mathrm{mM}$-EDTA (Invitrogen).

\section{Cell cycle analysis}

Intestinal cells (HT-29, Caco-2 and HIEC) were seeded at a density of 50000 onto six-well culture flasks and allowed to adhere for $24 \mathrm{~h}$. Thereafter, the medium was replaced and incubated for another $24 \mathrm{~h}$ in the presence or absence of the test compounds. Cells were trypsinized, pelleted by centrifugation at $500 \mathrm{~g}$ for $3 \mathrm{~min}$, washed twice with PBS and adjusted to $1 \times 10^{6}$ cells $/ \mathrm{ml}$. Cells were then fixed by suspending the cells at $4^{\circ} \mathrm{C}$ in ethanol for $24 \mathrm{~h}$. Thereafter, the suspension was centrifuged for $3 \mathrm{~min}$ at $500 \mathrm{~g}$, and the pellet was washed twice in $38 \mathrm{~mm}$-sodium citrate buffer $(\mathrm{pH} \mathrm{7.4)}$. After washing and centrifugation, cells were incubated with the dye solution containing 7-amino actin $(1 \mathrm{mg} / \mathrm{ml})$ and 1 unit DNase-free RNase in sodium citrate buffer. Cell cycle analysis was performed using a FACScan (Becton Dickinson, San Jose, CA, USA) and the software BD CellQuest ${ }^{\mathrm{TM}}$ Pro version 1.41 for data analysis.

\section{RNA extraction and cDNA synthesis}

Total RNA from intestinal cells was isolated using TRIzol reagent (Invitrogen) according to the manufacturer's instruction with slight modifications. Total RNA was quantified by measuring the absorbance at $260 \mathrm{~nm}$, and the purity was checked by the $260 / 280 \mathrm{~nm}$ absorbance ratio. cDNA synthesis was carried out in a reaction volume of $50 \mu \mathrm{l}$ containing 500 ng RNA, 50 mM-2-amino-2-hydroxymethyl-1,3-propanediol hydrochloride ( $\mathrm{pH} 8 \cdot 3$ ), $75 \mathrm{~mm}-\mathrm{KCl}, 3 \mathrm{mM}-\mathrm{MgCl}_{2}$, $10 \mathrm{~mm}$-dithiothreitol, $100 \mathrm{ng}$ oligodeoxythymidine 15 primer, $500 \mu \mathrm{M}$ of each deoxynucleotide triphosphate (dATP, dGTP, dCTP and dTTP), 10 units ribonuclease inhibitor and 200 units Moloney murine leukaemia virus RT; all reagents were obtained from Invitrogen. The samples were incubated at $37^{\circ} \mathrm{C}$ for $60 \mathrm{~min}$, followed by an incubation at $95^{\circ} \mathrm{C}$ for $15 \mathrm{~min}$.

\section{Analysis of mRNA expression (real-time quantitative PCR)}

mRNA expression of cell cycle genes such as cyclins (cyclin A, B, D, E), cyclin-dependent kinase inhibitors (CDKI) and p53 were determined in intestinal cells using the real-time PCR technique on a 7500 Real Time PCR System (Applied Biosystems, Darmstadt, Germany) and TaqMan ${ }^{\circledR}$ PCR master mix (Eurogentec, Köln, Germany). Gene-specific primers and probes used in the present study (Table 1) were designed using the sequences accessible in the NCBI Reference Sequence and the software Primer Express 3.0 (Applied Biosystems). Primer and probe sequences were chosen to prevent homologies to undesired genes and other coding sequences and checked by BLAST ${ }^{\mathrm{TM}}$ software. To exclude amplification from possible DNA contamination, the probes were designed to overlap exon junctions in cDNA regions derived from intron-bearing genes. All probes were labelled with the fluorescent dyes 6-carboxy-fluorescein as reporter and 6-carboxy-tetramethyl-rhodamine as quencher. Primers were purchased from MWG Biotech (Ebersberg, Germany) and probes from Eurogentec (Seraing, Belgium). A total reaction volume of $25 \mu \mathrm{l}$ containing reaction buffer with $250 \mathrm{~nm}$ of each primer and $150 \mathrm{nM}$-probe and $1 \mu \mathrm{l} \mathrm{cDNA}$. The PCR running conditions were: $10 \mathrm{~min}$ of initial denaturation at $95^{\circ} \mathrm{C}$ followed by forty cycles of $30 \mathrm{~s}$ at $95^{\circ} \mathrm{C}, 30 \mathrm{~s}$ at $58^{\circ} \mathrm{C}$ for annealing, $30 \mathrm{~s}$ at $60^{\circ} \mathrm{C}$, and $15 \mathrm{~s}$ at $75^{\circ} \mathrm{C}$. Samples were run in triplicates. PCR results are shown as the relative expression level of normalized samples ( $\Delta$ cycle threshold $(\mathrm{Ct})$ ) in relation to the expression of the calibrator sample $\left(2^{-\Delta \Delta C t}\right)$, which was set at $100 \%$. The $\mathrm{Ct}$ value refers to the cycle number at which the PCR plot crosses the threshold line, $\Delta \mathrm{Ct}$ is calculated by subtracting the $\mathrm{Ct}$ value of the corresponding housekeeper gene GAP-DH (endogenous reference control) from the specific $\mathrm{Ct}$ value of the target gene. Finally, 
Table 1. Primers and TaqMan ${ }^{\circledR}$ probes for real-time RT-PCR amplifications

\begin{tabular}{|c|c|c|c|}
\hline Gene & Accession no. & & Primers $\left(5^{\prime} \rightarrow 3^{\prime}\right)$ \\
\hline \multirow[t]{3}{*}{ GAP-DH } & NM_002046 & FP & CCACATCGCTCAGACACCAT \\
\hline & & BP & GTGACCAGGCGCCCAATA \\
\hline & & Probe & AGGTCGGAGTCAACGGATTTGG \\
\hline \multirow[t]{3}{*}{ Cyclin A } & NM_001237 & FP & TGCCTTTCATTTAGCACTCTACACA \\
\hline & & $\mathrm{BP}$ & TTAAGACTTTCCAGGGTATATCCAGTC \\
\hline & & Probe & CGGGACAAAGCTGGCCTGAATCATTAATA \\
\hline \multirow[t]{3}{*}{ Cyclin B } & NM_031966 & FP & GCTGCTGCCTGGTGAAGAG \\
\hline & & BP & CGCCTTATTTTCAGCATTAATTTTC \\
\hline & & Probe & ATGGCGCTCCGAGTCACCAGGAA \\
\hline \multirow[t]{3}{*}{ Cyclin E } & NM_001238 & FP & CGGCTCGCTCCAGGAA \\
\hline & & $\mathrm{BP}$ & TCGATTTTGGCCATTTCTTCA \\
\hline & & Probe & ACCGTTTTTTTTGCAGGATCCA \\
\hline \multirow[t]{3}{*}{ Cyclin D } & NM_053056 & FP & CCGTCCATGCGGAAGATC \\
\hline & & BP & TGCAGGCGGCTCTTTTTC \\
\hline & & Probe & ATGCTGGAGGTCTGCGAGGAACAGAAGT \\
\hline \multirow[t]{3}{*}{ p21 $1^{c i p 1}$} & NM_078467 & $\mathrm{FP}$ & CTGGAGACTCTCAGGGTCGAA \\
\hline & & BP & GGCTTAGGGCTTCCTCTTGGA \\
\hline & & Probe & ACGGCGGCAGACCAGCATGA \\
\hline \multirow[t]{3}{*}{$\mathrm{p} 27^{k i p 1}$} & NM_004064 & $\mathrm{FP}$ & CCGGTGGACCACGAAGAGT \\
\hline & & BP & GCTCGCCTCTTCCATGTCTC \\
\hline & & Probe & AACCCGGGACTTGGAGAAGCACTGC \\
\hline \multirow[t]{3}{*}{ p53 } & NM_000546 & FP & TAACAGTTCCTGCATGGGCGGC \\
\hline & & $\mathrm{BP}$ & AGGACAGGCACAAACACGCACC \\
\hline & & Probe & CGGAGGCCCATCCTCACCATCATCA \\
\hline
\end{tabular}

$\mathrm{BP}$, backward primer; FP, forward primer.

$\Delta \Delta \mathrm{Ct}$ is obtained by subtracting the $\Delta \mathrm{Ct}$ of each experimental sample from the $\Delta \mathrm{Ct}$ of the calibrator sample.

\section{Detection of receptor phosphorylation}

Nearly (70-80\%) confluent HT-29 cultures were incubated in Dulbecco's modified Eagle's medium with $10 \%$ fetal calf serum for $24 \mathrm{~h}$. Subsequently, reagents were added in concentrations indicated in the legends of the figures. After incubation, cells were trypsinized, washed and lysed with extraction buffer. Protein concentration was measured using the BioRad protein assay kit (Richmond, CA, USA). The Proteome Profiler ${ }^{\mathrm{TM}}$ array, human phospho-receptor tyrosine kinase array kit to identify the phosphorylation of forty-two different receptor tyrosine kinases, was used according to the manufacturer's instructions (R\&D Systems, Minneapolis, MN, USA) loading $250 \mu \mathrm{g}$ protein/membrane. Blots were developed by applying the chemiluminescence detection kit ECL-Plus (Amersham Biosciences, Arlington Heights, IL, USA). Spot intensity was then analysed with the software Biocat Software (Köln) and density is expressed as area under the curve.

\section{Detection of mitogen-activated protein kinase phosphorylation}

After incubation with oligosaccharides as indicated in the figures, cells were washed with PBS, solubilized in lysis buffer and $300 \mu \mathrm{g}$ total protein were used for the human phospho-MAP array (R\&D Systems, Heidelberg, Germany) according to the manufacturer's protocol. Briefly, arrays were incubated with whole-cell lysates overnight at $4^{\circ} \mathrm{C}$ and washed with the supplied washing buffer. Arrays were then incubated with anti-phosphotyrosine-horseradish peroxidase antibodies for $2 \mathrm{~h}$ at room temperature before incubation with a chemiluminescent reagent and film exposure; spot intensity was then analysed applying the software Biocat Software and expressed as area under the curve.

\section{Statistical analysis}

Data were evaluated by ANOVA and statistical differences were tested by Bonferroni's test. For each variable at least three independent experiments were carried out. Results are expressed as means and their standard errors. All analyses were done using the GraphPad Software Prism 3 (San Diego, CA, USA); differences were considered significant at $P<0.05$.

\section{Results}

\section{Cell cycle analysis}

As a consequence of growth inhibition and differentiation cells were fixed to determine their specific cell cycle phase by using flow cytometry. The cell cycle histogram plots and distribution of cell populations in different cell cycle stages for HT-29 are shown in Figs. 1 and 2. It was observed that neutral as well as acidic HMO induced a cell cycle arrest in the $\mathrm{G} 2 / \mathrm{M}$ phase which was moderate at a concentration of $7.5 \mathrm{mg} / \mathrm{ml}$ but pronounced at $15 \mathrm{mg} / \mathrm{ml}$. Cell cycle analysis of controls without oligosaccharide exposure revealed that $73 \%$ of the HT-29 population was in the G0/G1 phase and $16 \%$ in the G2/M phase (Figs. 1(A) and 2(A)). HT-29 cells exposed to $7.5 \mathrm{mg} / \mathrm{ml}$ neutral HMO exhibited a similar distribution of cells among the different cell cycle phases (Fig. 1(B)). The higher dose of oligosaccharides $(15 \mathrm{mg} / \mathrm{ml})$ altered the cell population in a way that $42 \%$ of the cell population was in the G0/G1 phase and $44 \%$ in the G2/M phase 

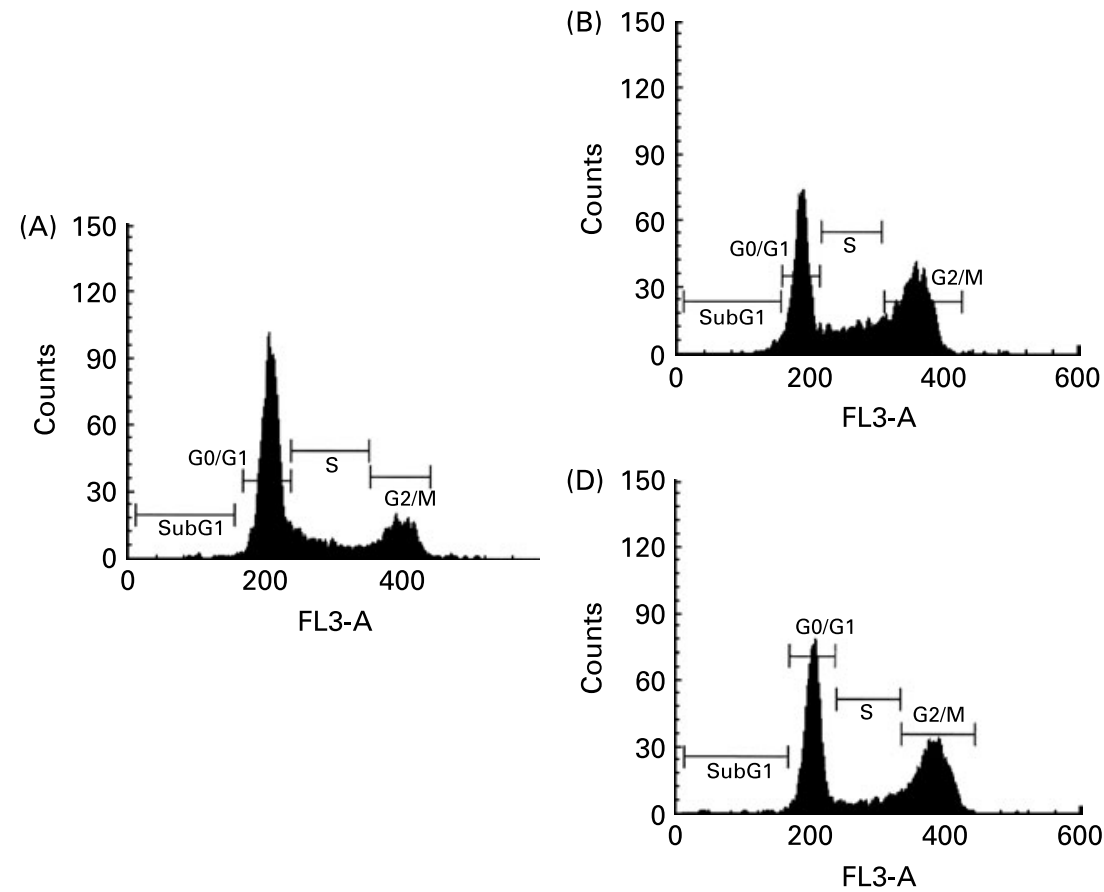
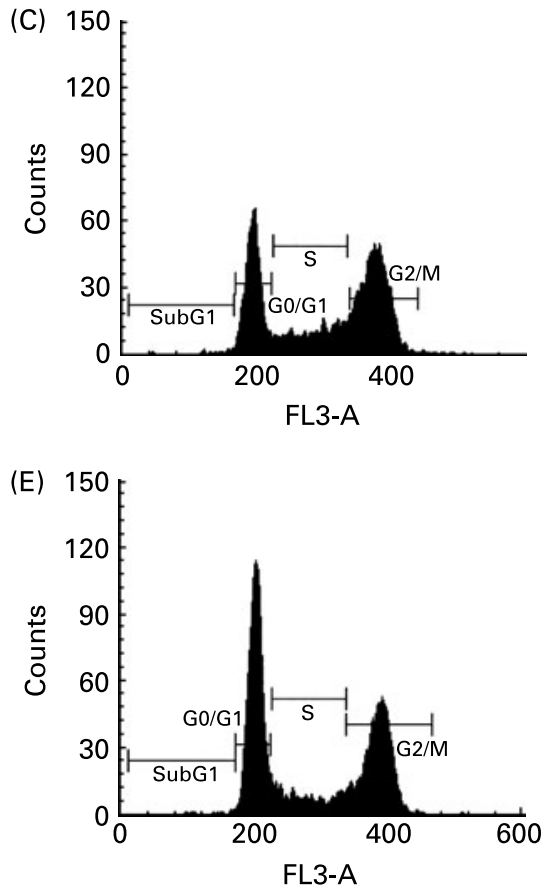

Fig. 1. Representative histograms of flow cytometric analysis of the cellular DNA content in control and oligosaccharide-treated HT-29 cells, stained with the fluorescence dye 7-aminoactinomycin. The cells were untreated $(A)$ or treated with $7.5 \mathrm{mg} / \mathrm{ml}(B, D)$ and $15 \mathrm{mg} / \mathrm{ml}(C, E)$ neutral $(B, C)$ or acidic $(D$, E) human milk oligosaccharides for $24 \mathrm{~h}$. Cell cycle distribution was performed as described in the Materials and methods. FL3-A, fluorescence intensity.

(Fig. 2(A)). After a $24 \mathrm{~h}$ treatment with the lower dose of acidic HMO (Figs. 1(D) and 2(B)), $72 \%$ of the cells were in the G0/G1 phase. This was balanced by a lower percentage of cells in the G2/M stages (16\%). Exposure of HT-29 for $24 \mathrm{~h}$ to the high dose of oligosaccharides resulted in a further accumulation of cells in the G2/M stage, $37 \%$ of the cell population were found to be in the G0/G1 stage and $35 \%$ accumulated in the G2/M stage (Fig. 2(B)).

In comparison to control cells, the proportion of cells in the G0/G1 phase significantly decreased in HIEC and Caco-2 cells after incubation with neutral and acidic HMO at a concentration of $15 \mathrm{mg} / \mathrm{ml}$ and thus accumulated in the $\mathrm{G} 2 / \mathrm{M}$ phase (44 and $33 \%$ in HIEC and Caco-2 cells, respectively). The number of cells in the $\mathrm{S}$ phase did not change significantly in both cell lines after incubation with oligosaccharides when compared to controls (Table 2).

Transcriptional regulation of cyclins, cyclin-dependent kinase inhibitors and tumour suppressors with quantitative real-time PCR

In order to relate cell cycle arrest to important cell cycle regulator genes such as cyclins and CDKI and tumour suppressor p53, we performed real-time PCR to quantify differences in the expression level of selected target genes. In Fig. 3, the data for the expression levels of cyclines are summarized for HT-29, HIEC and Caco-2 cells. After incubation of the cells with $15 \mathrm{mg} / \mathrm{ml}$ neutral or acidic HMO, mRNA expression
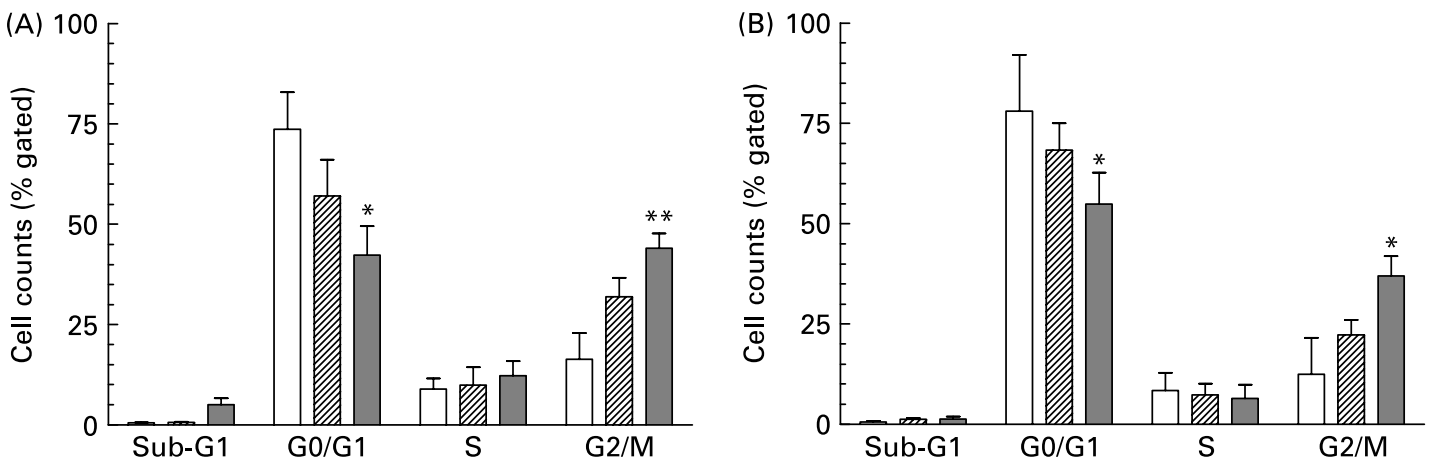

Fig. 2. Distribution of cell cycle phases based on histogram plots for HT-29 cells. The distribution of cell cycle phases is expressed as the percentage of gated cells in the G0/G1, S and G2/M phase of the cell cycle. Cells were treated with (A) neutral human milk oligosaccharides (四, $7.5 \mathrm{mg} / \mathrm{ml}$; $\square$, $15 \mathrm{mg} / \mathrm{ml})$ or (B) acidic human milk oligosaccharides ( $\mathbb{Z}, 7.5 \mathrm{mg} / \mathrm{ml} ; \square, 15 \mathrm{mg} / \mathrm{ml}$ ). Values are means with their standard errors depicted by vertical bars $(n 2)$. Mean values were significantly different from those of the control group: ${ }^{\star} P \leq 0.05,{ }^{\star \star} P \leq 0.01$. $\square$, Control. 
Table 2. Effects of oligosaccharides on cell cycle progression of HIEC and Caco-2 cells $†$ (Mean values for two independent experiments)

\begin{tabular}{|c|c|c|c|c|c|}
\hline & \multirow[b]{2}{*}{ Control } & \multicolumn{2}{|c|}{ Neutral HMO } & \multicolumn{2}{|c|}{ Acidic $\mathrm{HMO}$} \\
\hline & & $7.5 \mathrm{mg} / \mathrm{ml}$ & $15 \mathrm{mg} / \mathrm{ml}$ & $7.5 \mathrm{mg} / \mathrm{ml}$ & $15 \mathrm{mg} / \mathrm{m}$ \\
\hline \multicolumn{6}{|l|}{ HIEC } \\
\hline Sub G0/G1 & 0.54 & 1.21 & $6.76^{*}$ & 0.9 & $2 \cdot 1$ \\
\hline $\mathrm{Go} / \mathrm{G} 1$ & 69.5 & $60 \cdot 6$ & $55 \cdot 4^{\star}$ & $59 \cdot 0$ & $49 \cdot 3^{*}$ \\
\hline$S$ & $10 \cdot 3$ & 8.24 & $10 \cdot 3$ & $7 \cdot 4$ & 5.4 \\
\hline G2/M & $18 \cdot 3$ & 24.43 & $29 \cdot 5^{\star}$ & 22.5 & $44 \cdot 3^{* *}$ \\
\hline \multicolumn{6}{|l|}{ Caco-2 } \\
\hline Sub G0/G1 & 0.73 & 0.33 & 7.5 & 2.5 & 1.9 \\
\hline $\mathrm{G} 0 / \mathrm{G} 1$ & 63.4 & 63.5 & $53 \cdot 2^{*}$ & $60 \cdot 4$ & $50 \cdot 3^{*}$ \\
\hline $\mathrm{S}$ & 8.3 & 8.9 & 9.4 & $7 \cdot 1$ & $5 \cdot 8$ \\
\hline G2/M & $20 \cdot 4$ & $27 \cdot 3$ & $31 \cdot 2^{*}$ & 26.5 & $33 \cdot 2^{*}$ \\
\hline
\end{tabular}

HMO, human milk oligosaccharides.

Mean values were significantly different from those of the control group: ${ }^{*} P \leq 0.05,{ }^{* \star} P \leq 0.01$.

$\dagger$ For details of procedures, see Materials and methods. Intestinal cells were seeded at a density of $10^{6}$ cells and were allowed to attach for $24 \mathrm{~h}$. Finally, they were cultured without (control) or with 7.5 or $15 \mathrm{mg} / \mathrm{ml}$ neutral and acidic $\mathrm{HMO}$ for $24 \mathrm{~h}$. The distribution of cell cycle phases is expressed as percentage of gated cells in the G0/G1, S and G2/M phase of the cell cycle.

levels were determined using the target gene/housekeeping gene ratio by setting the control to $100 \%$. The expression level of cyclin $\mathrm{A}$, a regulator for $\mathrm{S} / \mathrm{G} 2$ transition, remained unchanged in all cell lines after the treatment with neutral HMO. In contrast, after incubation with acidic oligosaccharides, a moderate but significant increase was observed in HT-29 (146 (SEM 6) \%) and HIEC cells (132 (SEM 6) \%), whereas the cyclin A expression level in Caco-2 cells remained unaffected (Fig. 3). The mRNA expression levels of cyclin $\mathrm{B}$, which is responsible for the regulation of the G2/M cell cycle transition, were markedly increased in all cell lines after incubation with neutral or acidic oligosaccharides. After incubation with neutral HMO, the expression level of cyclin B in HT-29 was increased to 198 (SEM 12) \% and to 235 (SEM 9) \% after treatment with acidic HMO. Similar data were obtained for HIEC cells, i.e. both neutral and acidic HMO markedly increased cyclin B expression (221 (SEM 12) and 214 (SEM 8) \%, respectively). Also, in Caco-2 cells cyclin B expression was enhanced to 150 (SEM 7) \% by neutral HMO and 164 (SEM 5) \% by acidic HMO compared to controls. Cyclin D and $E$ which regulate the entry of cells into and the progression through the G1 phase of the cell cycle remained unchanged in all cell lines after oligosaccharide treatment.

We then investigated whether the block in cell cycle progression was accompanied by increased levels of CDKI such as $\mathrm{p} 21^{\text {cipl } 1}$ and $\mathrm{p} 27^{k i p 1}$. It is well known that both CDKI are able to induce cell cycle arrest and/or differentiation. Treatment of the undifferentiated cell lines HT-29 and HIEC with neutral and acidic HMO resulted in an enhanced expression of $\mathrm{p} 21^{\text {cipl }}$ and $\mathrm{p} 27^{\text {kipl }}$ (Table 3). In HT-29 cells, $7 \cdot 5$ and $15 \mathrm{mg} / \mathrm{ml}$ neutral HMO enhanced expression of $\mathrm{p} 21^{\text {cip } 1} 3 \cdot 7$ and 6.6-fold, respectively; acidic HMO were able to enhance mRNA levels of $\mathrm{p} 21^{\text {cipl }} 2 \cdot 8$ - and 4.1-fold, respectively. Similar observations were made for HIEC cells. p21 $1^{\text {cip } 1}$ expression increased 3.2-fold ( $15 \mathrm{mg} / \mathrm{ml}$ neutral HMO) and 3.6-fold $(15 \mathrm{mg} / \mathrm{ml}$ acidic HMO) compared to control experiments. p27 $7^{k i p 1}$ mRNA expression was enhanced 2.8- and 4.3-fold in HT-29 and HIEC cells when exposed to neutral HMO; treatment with the same amount of acidic HMO
(15 mg/ml) increased $\mathrm{p} 27^{k i p 1}$ mRNA expression 2.5- and 8.3fold in HT-29 and HIEC cells compared to controls. In contrast to HT-29 and HIEC cells, Caco-2 cells responded only with an increased $\mathrm{p} 21^{\text {cipl }}$ mRNA level but $\mathrm{p} 27^{\text {kipl }}$ levels remained unchanged after supplementation with HMO. Hence, neutral as well as acidic HMO induced an increase of $\mathrm{p} 21^{\text {cipl }}$ levels which reached a maximum of 210 (SEM 12) $\%(15 \mathrm{mg} / \mathrm{ml}$ neutral HMO) and 196 (SEM 10) \% (15 mg/ml acidic HMO) in comparison to control cells (100\%).

A well-known regulator of different checkpoints during the cell cycle is the tumour suppressor p53 which is able to regulate $\mathrm{G} 1$ or $\mathrm{G} 2$ transition. To get insight into the role of $\mathrm{p} 53$ in the observed G2/M arrest, we determined p53 mRNA levels in all cell lines after incubation with HMO, but no changes in p53 mRNA levels were observed in any cell line (Table 3).

\section{Influence of signal transduction pathways}

Changes in expression levels of cyclins or CDKI are a consequence of activation or inactivation of different signal cascades. Thus, we further investigated whether the effects of oligosaccharides are a result of influencing signalling pathways in the cell line HT-29, representing phenotypical undifferentiated cells. To screen the phosphorylation of several receptors and MAPK in HT-29 cells, we used the protein profiling array to detect different phosphorylation events. Results are shown in Fig. 4 for receptor phosphorylation.

Incubation with both neutral and acidic HMO induced a dose-dependent phosphorylation of the ERF receptor within $10 \mathrm{~min}$ indicating that oligosaccharides could interact with the epidermal growth factor receptor (EGFR). The effects of acidic oligosaccharides were more pronounced than the neutral oligosaccharide effects. Acidic HMO concentrations of 7.5 and $15 \mathrm{mg} / \mathrm{ml}$ induced an EGFR phosphorylation up to 247 (SEM 3) and 447 (SEM 34) \% compared to untreated cells $(100 \%)$. Neutral HMO were also able to affect EGFR phosphorylation and enhanced its phosphorylation to 168 (SEM 6) and 284 (SEM 8) \% at 7.5 and $15 \mathrm{mg} / \mathrm{ml}$, respectively. The effect of HMO was EGFR-specific because no other receptor phosphorylation was observed. 

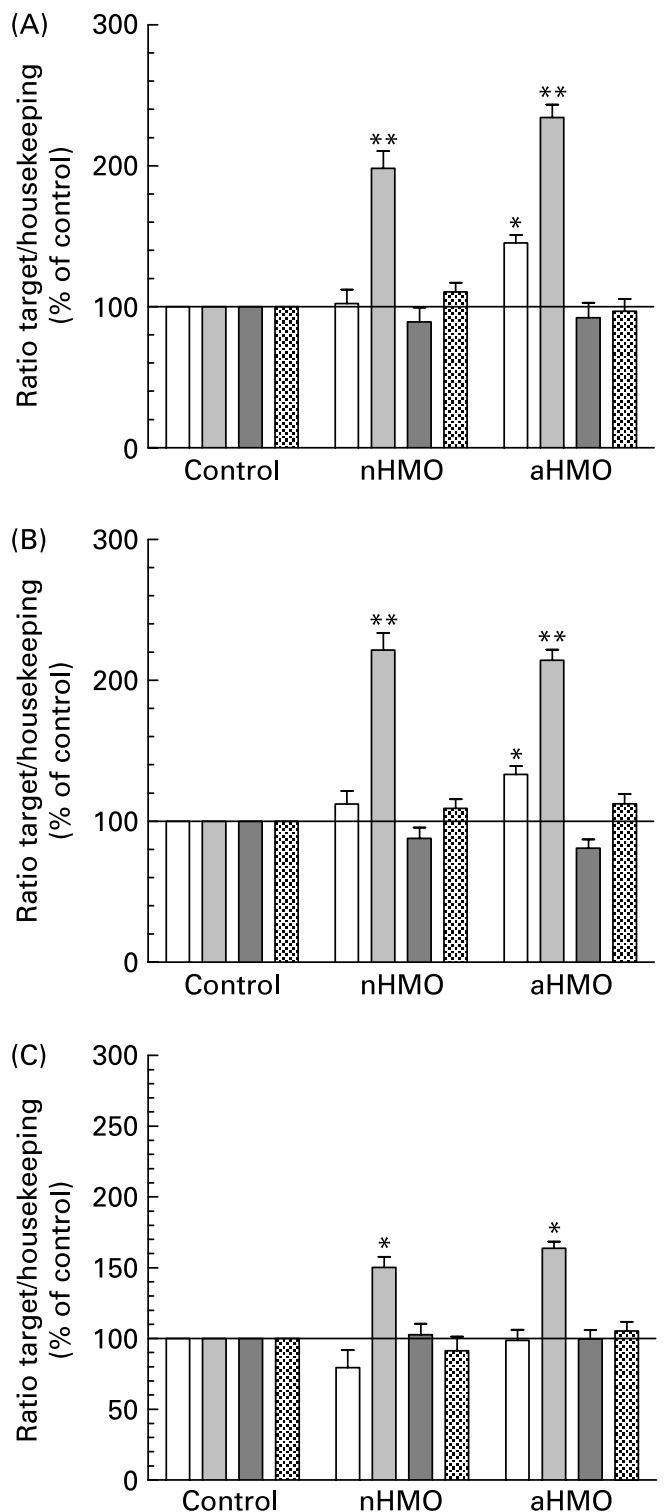

Fig. 3. Changes of mRNA expression levels of cell cycle genes in intestinal HT-29 (A), HIEC (B) and Caco-2 (C) cells with quantitative real-time PCR. Cells were treated with $15 \mathrm{mg} / \mathrm{ml}$ neutral $(\mathrm{nHMO})$ or acidic human milk oligosaccharides (aHMO) after reaching a confluency of $30 \%$ over $72 \mathrm{~h}$. Data were analysed as $2^{-\Delta \Delta C t}(\mathrm{Ct}$, cycle threshold). Values are means of the percentage of controls with their standard errors depicted by vertical bars $(n 3)$. Mean values were significantly different from those of the control group: ${ }^{\star} P \leq 0.05,{ }^{\star *} P \leq 0.01$. $\square$, Cyclin A/GAP-DH; $\square$, cyclin B/GAP-DH; $\square$, cyclin D/GAP-DH; $:$, cyclin E/GAP-DH.

As a consequence of receptor phosphorylation different signal pathways could be involved. To determine whether different MAPK were further activated we used the MAPK array to investigate how and to which extent oligosaccharides are able to induce downstream events from EGFR signalling. As shown in Fig. 5, the analysis of these signalling pathways revealed a role for p38 MAPK and extracellular signal-regulated kinase (ERK) 1/2 which were most significant on p38 MAPK. Phosphorylation and activation of different p38 MAPK subtypes, especially $\mathrm{p} 38 \alpha$ and $\mathrm{p} 38 \delta$ in HT-29 cells, was induced by acidic HMO (Fig. 5(A)) and to a lesser extent, but still significantly, by neutral HMO (Fig. 5(B)). Furthermore, the activation of $\mathrm{p} 38 \alpha$ was stronger than that of p38 in HMO-treated cells within $30 \mathrm{~min}$. In addition, PKB$\beta / A k t$ (Akt2), a growth factor-regulated protein kinase, and the downstream kinase ERK1 have emerged as critical enzymes in signal transduction pathways involved in cell proliferation and apoptosis. We have shown that both were activated by $\mathrm{HMO}$ at concentrations of 7.5 and $15 \mathrm{mg} / \mathrm{ml}$.

\section{Discussion}

The intestine is a continuously renewing tissue that constantly undergoes proliferation, differentiation and apoptosis. Recently, we reported that the exposure of the intestinal cell lines HT-29, HIEC and Caco-2 to HMO significantly inhibited cell proliferation. Whereas neutral oligosaccharides exerted an anti-proliferative effect along with a significant induction of apoptosis and a slight increase in differentiation, acidic oligosaccharides inhibited intestinal cell proliferation only by an induction of alkaline phosphatase activity as a marker of differentiation ${ }^{(13)}$. To understand the effects of oligosaccharides on growth-associated events of intestinal cells, flow cytometric analyses were carried out. Cytometric analyses showed significant changes of the cell cycle pattern in HT-29, HIEC and Caco-2 cells following oligosaccharide treatment for $24 \mathrm{~h}$ (Figs. 1 and 2; Table 2). In control experiments, the major proportion of cells was arrested in the G0/G1 phase. After treatment with neutral or acidic HMO, cells accumulated in the G2/M phase of the cell cycle (44, 30 and 31 of HT-29, HIEC and Caco-2 cells, respectively, after exposure to neutral oligosaccharides; 37, 44 and $33 \%$ of HT-29, HIEC and Caco2 cells, respectively, after treatment with acidic HMO). This leads to the conclusion that the potent anti-proliferative effect of acidic and neutral oligosaccharides is coupled to an extensive G2/M arrest in intestinal epithelial cells. We further investigated whether the G2/M cell cycle arrest due to the exposure to oligosaccharides was associated with changes in mRNA levels for key proteins regulating the cell cycle. Progression through the cell cycle is regulated by CDK, a family of serine/threonine protein kinases which phosphorylate a variety of proteins for cell cycle control ${ }^{(23,24)}$. The cellular concentrations of cyclins vary depending on the cell cycle stage, whereas the levels of $\mathrm{CDK}$ remain relatively stable, but must bind to the appropriate cyclin in order to be activated. Therefore, cyclin mRNA expression levels were determined and correlated to flow cytometric events.

After $24 \mathrm{~h}$ of oligosaccharide treatment, there was no significant change in cyclin D and E mRNA levels suggesting that cells enter the cell cycle and proceed to G2. Previous studies in intestinal cells demonstrated that cyclin D1 is essential for the progression through the cell cycle ${ }^{(25,26)}$. The present data also indicate that additional cyclins may be responsible for transition and arrest, e.g. cyclin B1, a cell cycle regulatory protein that is generally induced at the G2/M transition and becomes deactivated as the cell exits mitosis. We found that cyclin B1 expression increased after HMO treatment (Fig. 3). This may prevent the cells from entering the $\mathrm{G} 2 / \mathrm{M}$ stage, thus corroborating the observed cell cycle arrest at $\mathrm{G} 2 / \mathrm{M}$ and the reduced cell proliferation when oligosaccharides were applied. This is in accordance with several other studies which had shown that blocking 
Table 3. Effects of oligosaccharides on cell cycle progression of HT-29, HIEC and Caco-2 cells $\dagger$ (Mean values with their standard errors for three independent experiments)

\begin{tabular}{|c|c|c|c|c|c|c|c|c|c|c|}
\hline & \multirow{2}{*}{\multicolumn{2}{|c|}{ Control }} & \multicolumn{4}{|c|}{ Neutral HMO } & \multicolumn{4}{|c|}{ Acidic HMO } \\
\hline & & & \multicolumn{2}{|c|}{$7.5 \mathrm{mg} / \mathrm{ml}$} & \multicolumn{2}{|c|}{$15 \mathrm{mg} / \mathrm{ml}$} & \multicolumn{2}{|c|}{$7.5 \mathrm{mg} / \mathrm{ml}$} & \multicolumn{2}{|c|}{$15 \mathrm{mg} / \mathrm{ml}$} \\
\hline & Mean & SEM & Mean & SEM & Mean & SEM & Mean & SEM & Mean & SEM \\
\hline \multicolumn{11}{|l|}{ HT-29 } \\
\hline $\mathrm{p} 21^{\operatorname{cip} 1}$ & $2 \cdot 31$ & 0.21 & 8.65 & $1 \cdot 20^{\star \star \star}$ & $15 \cdot 25$ & $2 \cdot 64^{\star \star \star}$ & $6 \cdot 48$ & $1 \cdot 54^{\star \star \star}$ & $9 \cdot 67$ & $1 \cdot 88^{\star \star \star}$ \\
\hline $\mathrm{p} 27^{\text {kip1 }}$ & 1.59 & 0.10 & 3.25 & $0.44^{*}$ & 4.56 & $0.99^{*}$ & $2 \cdot 66$ & $0.41^{*}$ & 4.08 & $0.57^{\star \star}$ \\
\hline p53 & 3.65 & 0.29 & 2.69 & 1.41 & $4 \cdot 12$ & 0.59 & 3.06 & 0.41 & $4 \cdot 14$ & 0.47 \\
\hline \multicolumn{11}{|l|}{ HIEC } \\
\hline p21 $1^{\text {cip } 1}$ & 3.69 & 0.43 & 6.55 & $0.75^{\star \star}$ & $11 \cdot 74$ & $2 \cdot 05^{\star \star}$ & 5.98 & $0.51^{\star *}$ & $13 \cdot 5$ & $2 \cdot 87^{\star *}$ \\
\hline $\mathrm{p} 27^{\text {kip1 }}$ & 0.69 & 0.09 & 1.56 & $0.47^{\star}$ & 2.99 & $0.58^{\star \star}$ & 1.57 & $0.42^{*}$ & $5 \cdot 73$ & $0.39^{\star \star}$ \\
\hline p53 & $5 \cdot 69$ & 0.41 & $6 \cdot 87$ & 2.56 & 8.74 & 3.68 & 7.08 & $2 \cdot 54$ & $7 \cdot 41$ & $2 \cdot 62$ \\
\hline \multicolumn{11}{|l|}{ Caco-2 } \\
\hline $\mathrm{p} 21^{\text {cip } 1}$ & $3 \cdot 61$ & 0.35 & $5 \cdot 25$ & 1.46 & $7 \cdot 69$ & $1 \cdot 56^{\star}$ & $6 \cdot 98$ & $2 \cdot 04^{*}$ & 7.09 & $2 \cdot 10^{\star}$ \\
\hline $\mathrm{p} 27^{k i p 1}$ & $5 \cdot 24$ & 0.52 & 4.56 & 0.62 & 5.08 & 0.41 & 5.88 & 0.85 & 4.80 & 1.08 \\
\hline p53 & 3.04 & 0.33 & 2.65 & 0.41 & 3.65 & 0.41 & 3.96 & 0.84 & $2 \cdot 74$ & 0.41 \\
\hline
\end{tabular}

$\mathrm{HMO}$, human milk oligosaccharides.

Mean values were significantly different from those of the control group: ${ }^{\star} P \leq 0.05,{ }^{\star \star} P \leq 0.01,{ }^{\star \star \star} P \leq 0.001$.

$\dagger$ For details of procedures, see Materials and methods. Intestinal cells were seeded at a density of $10^{6}$ cells and were allowed to attach for $24 \mathrm{~h}$. Finally, they were cultured without (control) or with 7.5 or $15 \mathrm{mg} / \mathrm{ml}$ neutral and acidic HMO for $24 \mathrm{~h}$. Real-time PCR was carried out using cell cycle-specific primer and probes (see Table 1). Data were analysed as $2^{-\Delta \Delta \mathrm{Ct}}$ (Ct, cycle threshold) and given as means of the percentage of controls.

cell cycle progression at $\mathrm{G} 2 / \mathrm{M}$ was due to increasing cyclin B1 expression in different cancer cell lines ${ }^{(27)}$.

In addition, the G2/M arrest seen in HT-29 and HIEC cells, but not in Caco-2 cells, was associated with a slightly increased mRNA expression level of cyclin A after incubation with acidic oligosaccharides. However, there was no response to an exposure to neutral HMO. If cyclin A were necessary for S/G2 phase transition one might speculate that the G2/M arrest in HT-29 and HIEC cells treated with acidic oligosaccharides is coupled to an increase in both cyclin $\mathrm{A}$ and $\mathrm{B}^{(27,28)}$.

The transition through the cell cycle is mediated not only by different time-dependent expression of cyclins but also by the activation of CDK. The interaction of cyclins with their corresponding CDK promotes further activation of target proteins responsible for cell cycle transition. On the other hand, CDKI of the $C I P / K I P$ family are negative regulators of cell cycle progression and CDKI such as $\mathrm{p} 21^{\text {cipl }}$ and $\mathrm{p} 27^{\text {kipl }}$ were able to inhibit the formation of cyclin-CDK complexes. The inactivation of the $\mathrm{CDK}$-cyclin $\mathrm{B}$ complex by its subsequent binding to $\mathrm{p} 21^{\text {cipl }}$ is one of the probable mechanisms of $\mathrm{G} 2 / \mathrm{M}$ arrest. The present data demonstrate (Table 3 ) a significant up-regulation of $\mathrm{p} 21^{\text {cip } 1} \mathrm{mRNA}$ expression, indicating its role in oligosaccharide-mediated G2/M arrest in all intestinal cell lines. It has recently been shown that $\mathrm{p} 21^{\text {cipl }}$ interacts with cyclin D throughout the cell cycle, whereas interaction between $\mathrm{p} 21^{\text {cip } 1}$ and cyclin A or cyclin B occurs in the later part of the cell cycle ${ }^{(29,30)}$. Thus, the G2/M growth arrest we observed may well be a p21-dependent mechanism. Several lines of evidence suggested that $\mathrm{p} 21^{\text {cip } 1}$ and $\mathrm{p} 27^{k i p 1}$ exert similar effects on cyclin-CDK complexes and cell cycle progression but other observations indicate that these CDKI have no overlapping functions and are not biologically equivalent, because of their differentially regulated expression ${ }^{(31,32)}$. In comparison to control cells HMO were able to enhance mRNA levels of p2 $7^{k i p l}$

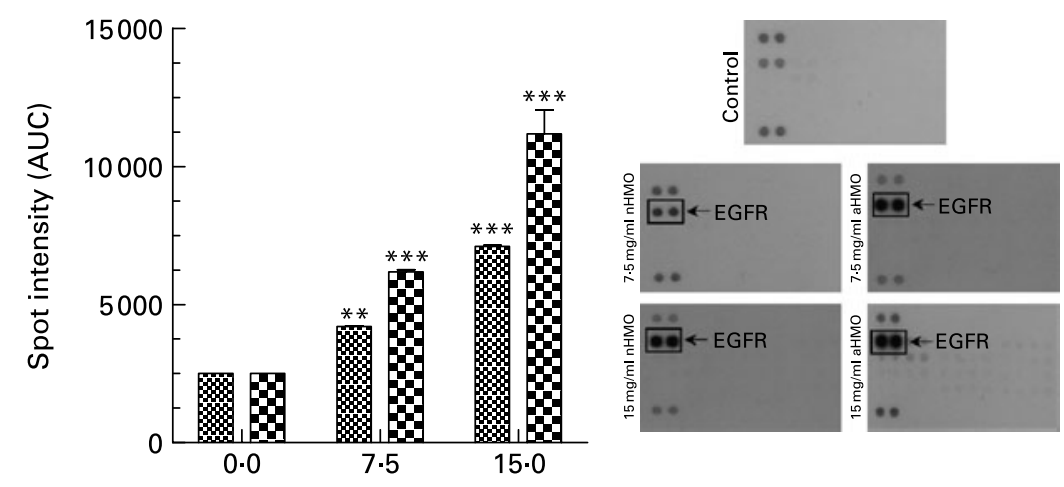

Fig. 4. Receptor tyrosine kinase antibody array analysis. Cells were treated with neutral human milk oligosaccharides (nHMO; charides (aHMO; $\mathbf{*})$ ( 7.5 and $15 \mathrm{mg} / \mathrm{ml})$ for $10 \mathrm{~min}$. Lysate was prepared according to the manufacturer's instructions. Phospho-receptor tyrosine kinase array was used to detect phosphorylation of these receptor tyrosine kinases in HT-29. The signal was detected by chemiluminescence and the spot intensity is shown. Values are means of the percentage of controls with their standard errors depicted by vertical bars $(n 3)$. Mean values were significantly different from those of the control group: ${ }^{\star \star} P \leq 0.01,{ }^{* \star} P \leq 0.001$. AUC, area under the curve; EGFR, epidermal growth factor receptor. 
(A)

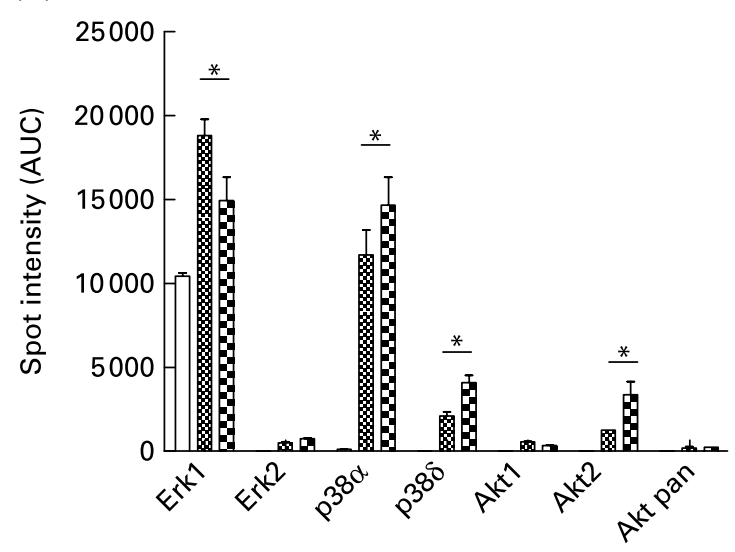

(B)

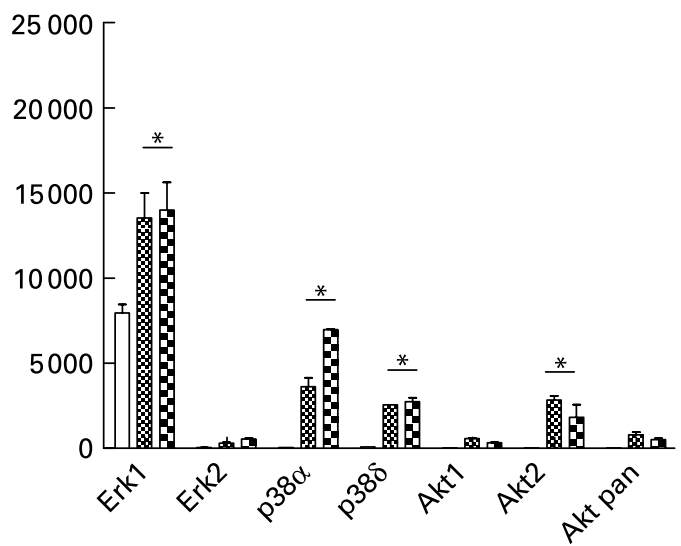

Fig. 5. Detection of phosphorylated mitogen-activated protein kinases in untreated HT-29 cells ( $\square$ ) and HT-29 cells treated with (A) neutral human milk oligosac-

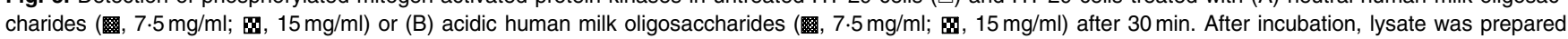
and $300 \mu \mathrm{g}$ lysate were used for each assay. Array signals from scanned X-ray film images were analysed using image analysis software and expressed as spot pixel density. Values are means with their standard errors depicted by vertical bars $(n 2)$. Mean values were significantly different: ${ }^{\star} P \leq 0 \cdot 05$. AUC, area under the curve.

significantly in HIEC and HT-29 cells whereas in the more differentiated Caco-2 cells oligosaccharides failed to further increase p $27^{k i p 1}$ mRNA levels (Table 3). The present results indicate distinct roles of these CDKI, i.e. p2 $1^{\text {cipl }}$ promotes cell cycle arrest and p $27^{k i p 1}$ induces cell differentiation. Cells arrested in the $\mathrm{G} 2 / \mathrm{M}$ phase concomitant with enhanced $\mathrm{p} 21^{\text {cip } 1}$ mRNA and protein levels are often discussed in the context of a p53-dependent mechanism ${ }^{(33-35)}$. This p53-independent $\mathrm{G} 2 / \mathrm{M}$ regulation was also seen in the present experiments; however, p53 was not changed in the intestinal cell lines tested in comparison to the control cells (Table 3).
The activation of EGFR and transmission of the extracellular signal through different signalling pathways (the ERK pathway, the stress-activated c-Jun N-terminal kinase and the p38/HOG kinase pathways) in order to provoke cell progression is a well-known and accepted process ${ }^{(36,37)}$. However, recent studies suggest that the EGFR pathway is not simply a growth-promoting signalling pathway, but phosphorylated EGFR also mediates $\mathrm{p} 21^{\text {cip } 1}$ expression and growth arrest or apoptosis via modulation of signalling pathways ${ }^{(38,39)}$. From the present study two interesting findings have emerged: firstly, we observed that oligosaccharides were able to induce EGFR phosphorylation and,

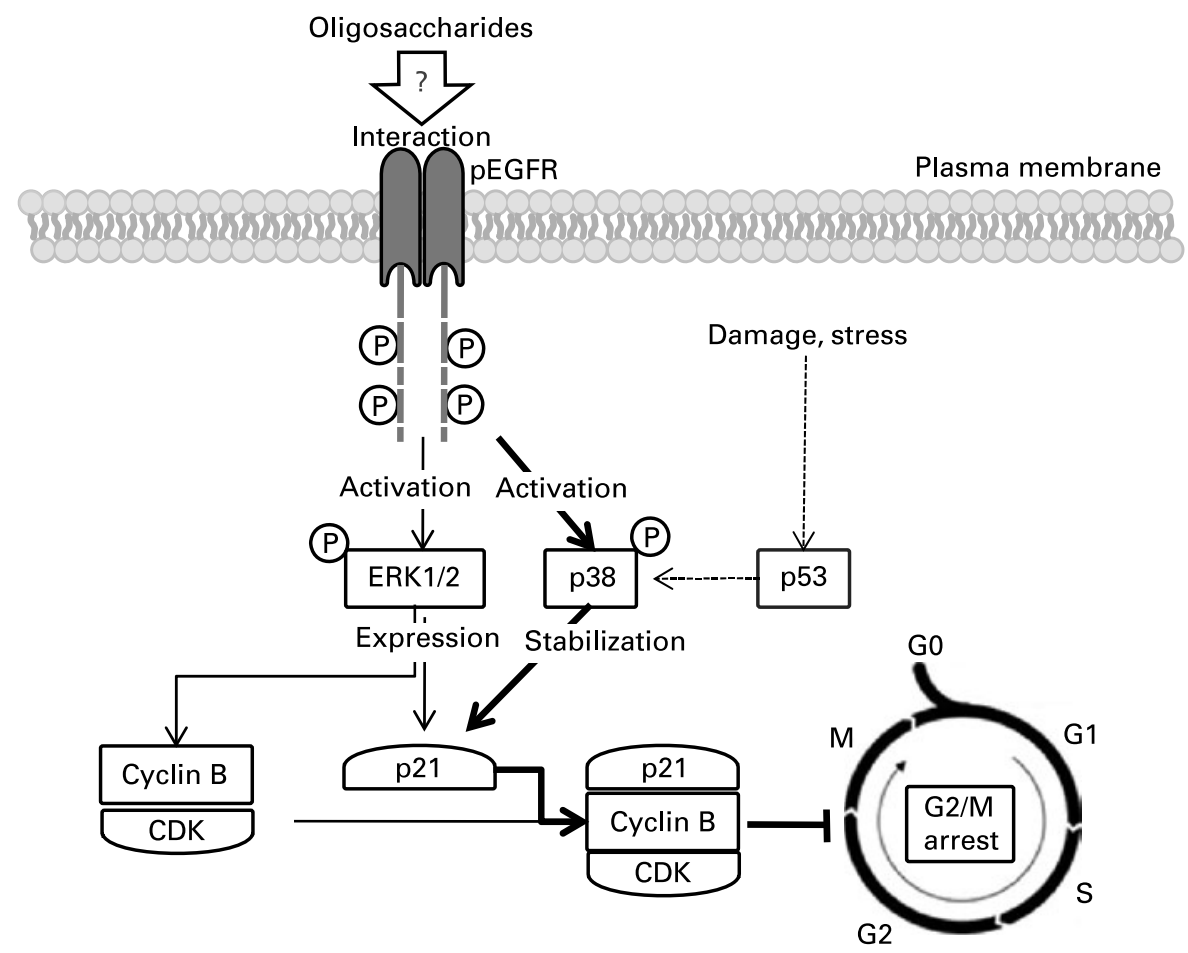

Fig. 6. Proposed mechanism for intracellular pathway-mediated G2/M arrest. CDK, cyclin-dependent kinase; EGFR, epidermal growth factor receptor. 
secondly, we have confirmed that the EGFR/Ras/Raf/ERK pathway is involved. As shown in Figs. 4 and 5 neutral HMO as well as acidic HMO induce a potent phosphorylation of the EGFR within $10 \mathrm{~min}$ and, in addition, multiple downstream kinases such as p38 $\alpha, \mathrm{p} 38 \delta$, ERK1 and Akt-2/PKB were activated within $30 \mathrm{~min}$. As the EGFR is a glycoprotein and interactions of oligosaccharides with glycoprotein receptors are well documented it is conceivable that oligosaccharide fractions possess a general motif inducing the effects we observed. The crosstalk between EGFR phosphorylation, p38 activation and $\mathrm{p} 21^{\text {cipl }}$ expression is observed in a variety of in vitro studies. For example, the p38 MAPK pathway can activate the Sp1/ Sp3 transcription factors and this seems necessary for EGFRdependent transactivation of the $\mathrm{p} 21^{\text {cipl }}$ promoter $^{(40-42)}$.

Based upon the present observations we conclude that oligosaccharides are able to activate $\mathrm{p} 21^{\text {cip } 1}$ expression and stabilization via EGFR and p38 kinase phosphorylation. Fig. 6 summarizes a mechanism how oligosaccharides induce cell cycle arrest by possibly interacting with EGFR.

In conclusion, we identify HMO as ingredients which were able to induce growth arrest of intestinal cells by modulating EGFR signal pathways and cell cycle-associated gene expression. However, whether the ability of oligosaccharides to inhibit intestinal cell proliferation has implications for a different effect on the intestinal growth regulation in human milk-fed $v$. formula-fed infants is not known yet and requires further investigation.

\section{Acknowledgements}

There were no conflicts of interest among authors of the present study. S. K. had full access to all of the data in the study and takes responsibility for the integrity of the data and the accuracy of the data analysis. The authors greatly appreciate the excellent technical assistance of Nadine Metz. S. K. performed all the laboratory work, analysis of the data derived from the various experimental procedures, statistical analysis and wrote the manuscript; C. K. and S. R. participated in planning the analyses and in the critical revision of the manuscript. This study was supported by Wyeth Nutrition (USA).

\section{References}

1. Sharon N \& Ofek I (2000) Safe as mother's milk: carbohydrates as future anti-adhesion drugs for bacterial diseases. Glycoconj $J$ 17, 659-664.

2. Kunz C, Rudloff S, Baier W, Klein N \& Strobel S (2000) Oligosaccharides in human milk: structural, functional, and metabolic aspects. Annu Rev Nutr 20, 699-722.

3. Bode L, Kunz C, Muhly-Reinholz M, Mayer K, Seeger W \& Rudloff S (2004) Inhibition of monocyte, lymphocyte, and neutrophil adhesion to endothelial cells by human milk oligosaccharides. Thromb Haemost 92, 1402-1410.

4. Bode L, Rudloff S, Kunz C, Strobel S \& Klein N (2004) Human milk oligosaccharides reduce platelet-neutrophil complex formation leading to a decrease in neutrophil $\beta 2$ integrin expression. J Leukocyte Biol 76, 1-7.

5. Kobata A \& Ginsburg V (1972) Oligosaccharides of human milk. 3. Isolation and characterization of a new hexasaccharide, lacto- $N$-hexaose. J Biol Chem 247, 1525-1529.
6. Kobata A, Yamashita K \& Tachibana Y (1978) Oligosaccharides from human milk. Methods Enzymol 50, 216-220.

7. Kunz C, Rudloff S, Hintelmann A, Pohlentz G \& Egge H (1996) High-pH anion-exchange chromatography with pulsed amperometric detection and molar response factors of human milk oligosaccharides. $J$ Chromatogr B Biomed Appl 25, 211-221.

8. Parkkinen J \& Finne J (1987) Isolation of sialyl oligosaccharides and sialyl oligosaccharide phosphates from bovine colostrum and human urine. Methods Enzymol 138, 289-300.

9. Kunz C \& Rudloff S (2000) Oligosaccharides in human milk: structural, functional and metabolic aspects. Annu Rev Nutr 20, 699-722.

10. Engfer MB, Stahl B, Finke B, Sawatzki G \& Daniel H (2000) Human milk oligosaccharides are resistant to enzymatic hydrolysis in the upper gastrointestinal tract. Am J Clin Nutr 71, 1589-1596.

11. Gnoth MJ, Kunz C, Kinne-Saffran E \& Rudloff S (2000) Human milk oligosaccharides are minimally digested in vitro. J Nutr 130, 3014-3020.

12. Gnoth MJ, Rudloff S, Kunz C \& Kinne RK (2001) Investigations of the in vitro transport of human milk oligosaccharides by a Caco- 2 monolayer using a novel high performance liquid chromatography-mass spectrometry technique. J Biol Chem 14, 34363-34370.

13. Kuntz S, Rudloff S \& Kunz C (2008) Oligosaccharides from human milk influence growth-related characteristics of intestinally transformed and non-transformed intestinal cells. Br J Nutr 99, 462-471.

14. Vermeulen K, Van Bockstaele DR \& Berneman ZN (2003) The cell cycle: a review of regulation, deregulation and therapeutic targets in cancer. Cell Prolif 36, 131-149.

15. Serrano M (2003) Proliferation: the cell cycle. Adv Exp Med Biol 532, 13-17.

16. Stein GH \& Dulic V (1998) Molecular mechanisms for the senescent cell cycle arrest. J Investig Dermatol Symp Proc 3, 14-18.

17. Dai Y \& Grant S (2003) Cyclin-dependent kinase inhibitors. Curr Opin Pharmacol 3, 362-370.

18. Mani S, Wang C, Wu K, Francis R \& Pestell R (2000) Cyclindependent kinase inhibitors: novel anticancer agents. Expert Opin Investig Drugs 9, 1849-1870.

19. Baghdassarian N \& French M (1996) Cyclin-dependent kinase inhibitors (CKIs) and hematological malignancies. Hematol Cell Ther 38, 152-158.

20. Li Y, Dowbenko D \& Lasky L (2002) AKT/PKB phosphorylation of $\mathrm{p} 21 \mathrm{Cip} / \mathrm{WAF} 1$ enhances protein stability of p21Cip/ WAF1 and promotes cell survival. J Biol Chem 17, 277-286.

21. Rudloff S, Obermeier S, Borsch CH, Pohlentz G, Hartmann R, Brösicke H, Lentze MJ \& Kunz C (2006) Incorporation of orally applied ${ }^{13} \mathrm{C}$-galactose into milk lactose and oligosaccharides. Glycobiology 16, 477-487.

22. Perreault N \& Beaulieu JF (1996) Use of the dissociating enzyme thermolysin to generate viable human normal intestinal epithelial cell cultures. Exp Cell Res 1, 354-364.

23. Nadella KS \& Kirschner LS (2005) Disruption of protein kinase A regulation causes immortalization and dysregulation of Dtype cyclins. Cancer Res 15, 10307-10315.

24. Ouyang W, Ma Q, Li J, Zhang D, Liu ZG, Rustgi AK \& Huang C (2005) Cyclin D1 induction through IkappaB kinase beta/ nuclear factor-kappaB pathway is responsible for arseniteinduced increased cell cycle G1-S phase transition in human keratinocytes. Cancer Res 15, 9287-9293.

25. Lewis RC, Bostick RM, Xie D, Deng Z, Wargovich MJ, Fina MF, Roufail WM \& Geisinger KR (2003) Polymorphism of the cyclin D1 gene, CCND1, and risk for incident sporadic colorectal adenomas. Cancer Res 63, 8549-8553. 
26. McKay JA, Douglas JJ, Ross VG, Curran S, Murray GI, Cassidy J \& McLeod HL (2000) Cyclin D1 protein expression and gene polymorphism in colorectal cancer. Int J Cancer 88, 77-81.

27. Dash BC \& El-Deiry WS (2005) Phosphorylation of p21 in G2/M promotes cyclin B-Cdc2 kinase activity. Mol Cell Biol 25, 3364-3387.

28. Ji P, Agrawal S, Diederichs S, et al. (2005) Cyclin A1, the alternative A-type cyclin, contributes to G1/S cell cycle progression in somatic cells. Oncogene 14, 2739-2744.

29. Li R, Hannon GJ, Beach D \& Stillman B (1996) Subcellular distribution of p21 and PCNA in normal and repair-deficient cells following DNA damage. Curr Biol 6, 189-199.

30. Harper JW, Elledge SJ, Keyomarsi K, et al. (1995) Inhibition of cyclin-dependent kinases by p21. Mol Biol Cell 6, 387-400.

31. Sherr CJ \& Roberts JM (1999) CDK inhibitors: positive and negative regulators of G1-phase progression. Genes Dev 13, $1501-1512$.

32. Blain SW, Montalvo E \& Massagué J (1997) Differential interaction of the cyclin-dependent kinase (Cdk) inhibitor p27Kip1 with cyclin A-Cdk2 and cyclin D2-Cdk4. J Biol Chem 272, 25863-25872.

33. Matsui TA, Sowa Y, Murata H, et al. (2007) The plant alkaloid cryptolepine induces p21WAF1/CIP1 and cell cycle arrest in a human osteosarcoma cell line. Int J Oncol 31, 915-922.

34. Sowa Y, Murata H, Takagi K, et al. (2007) The plant alkaloid cryptolepine induces p21WAF1/CIP1 and cell cycle arrest in a human osteosarcoma cell line. Int J Oncol 31, 915-922.

35. Aoki S, Kong D, Suna H, Sowa Y, Sakai T, Setiawan A \& Kobayashi M (2006) Aaptamine, a spongean alkaloid, activates p21 promoter in a p53-independent manner. Biochem Biophys Res Commun 342, 101-116.
36. Tarnawski AS \& Jones MK (1998) The role of epidermal growth factor (EGF) and its receptor in mucosal protection, adaptation to injury, and ulcer healing: involvement of EGF-R signal transduction pathways. J Clin Gastroenterol 27, S12-S20.

37. Sundaram MV (2006) RTK/Ras/MAPK signaling. WormBook 11, $1-19$.

38. Liu ZM \& Huang HS (2006) $\mathrm{As}_{2} \mathrm{O}_{3}$-induced c-Src/EGFR/ERK signaling is via Sp1 binding sites to stimulate p21WAF1/CIP1 expression in human epidermoid carcinoma A431 cells. Cell Signal 18, 244-255.

39. Matsumoto E, Hatanaka M, Bohgaki M \& Maeda S (2006) PKC pathway and ERK/MAPK pathway are required for induction of cyclin D1 and p21Waf1 during 12-o-tetradecanoylphorbol 13acetate-induced differentiation of myeloleukemia cells. Kobe $J$ Med Sci 52, 181-194.

40. Kuwahara I, Lillehoj EP, Lu W, Singh IS, Isohama Y, Miyata T \& Kim KC (2006) Neutrophil elastase induces IL-8 gene transcription and protein release through $\mathrm{p} 38 / \mathrm{NF}-\kappa \mathrm{B}$ activation via EGFR transactivation in a lung epithelial cell line. Am J Physiol Lung Cell Mol Physiol 291, 407-416.

41. Matsuo M, Sakurai H, Ueno Y, Ohtani O \& Saiki I (2006) Activation of MEK/ERK and PI3K/Akt pathways by fibronectin requires integrin alphav-mediated ADAM activity in hepatocellular carcinoma: a novel functional target for gefitinib. Cancer Sci 97, 155-162.

42. Xu K \& Shu HK (2007) EGFR activation results in enhanced cyclooxygenase- 2 expression through p38 mitogenactivated protein kinase-dependent activation of the $\mathrm{Sp} 1 / \mathrm{Sp} 3$ transcription factors in human gliomas. Cancer Res 67, 6121-6129. 